\title{
Attitude of Medical Students in Paraguay Towards Homosexuality
}

\author{
J Torales, I Barrios, A Torres, N Dunjó, MG Benítez, J Villalba, A Ventriglio, D Bhugra
}

\begin{abstract}
Introduction: The attitude of medical students towards homosexuality may affect the quality of care for homosexual patients. This study aimed to describe the attitude of medical students at the National University of Asuncion, Paraguay towards homosexuality.

Methods: This observational, cross-sectional study was conducted in June 2016 in consecutive medical students from the National University of Asunción (Santa Rosa del Aguaray branch), Paraguay. The 10 -item attitude towards homosexuality scale (EAH-10) was used to assess participants' acceptance/ rejection of homosexuals as individuals, homosexuality as a sexual orientation, and public manifestations of homosexuality.

Results: A total of 48 female and 29 male participants (mean age, $21 \pm 2$ years) were included. Most were Catholic (71.4\%), followed by non-Catholic Christian (10.4\%), agnostic (9.1\%), atheist (2.6\%), and other $(6.5 \%) .71 .4 \%$ reported having at least one homosexual friend. The mean EAH-10 score was 27.23 $\pm 9.379 .42 .9 \%$ of participants were indifferent or undecided in their attitude towards homosexuality and $28.6 \%$ were discriminatory. Having homosexual friends was associated with a lower EAH-10 score $(t=$ -3.447 [75], $\mathrm{p}=0.001)$.
\end{abstract}

Conclusion: Education about health issues of homosexuals is needed for medical students in Paraguay.

Key words: Attitude; Homosexuality; Students, medical

Prof Julio Torales, MD, MSc, IFAPA, MWPA (Hon), Head of the Socioanthropology Department, School of Medical Sciences, National University of Asunción (Santa Rosa Campus), Santa Rosa del Aguaray, Paraguay.

Iván Barrios, Teaching Assistant, Research Methodology Department, National University of Asunción, San Lorenzo, Paraguay.

Alexis Torres, Medical students, School of Medical Sciences, National University of Asunción (Santa Rosa Campus), Santa Rosa del Aguaray, Paraguay.

Ninfa Dunjó, Medical students, School of Medical Sciences, National University of Asunción (Santa Rosa Campus), Santa Rosa del Aguaray, Paraguay.

María Gloria Benítez, Medical students, School of Medical Sciences, National University of Asunción (Santa Rosa Campus), Santa Rosa del Aguaray, Paraguay.

Jorge Villalba, Teaching Assistant, Department of Medical Psychology, School of Medical Sciences, National University of Asunción (Santa Rosa Campus), Santa Rosa del Aguaray, Paraguay.

Antonio Ventriglio, Honorary Researcher, Department of Clinical and Experimental Medicine, University of Foggia, Foggia, Italy.

Dinesh Bhugra, Emeritus Professor of Mental Health and Cultural Diversity, King's College London, London, United Kingdom.

Address for correspondence: Prof Julio Torales, Socio-anthropology Department, School of Medical Sciences, National University of Asunción (Santa Rosa Campus), Santa Rosa del Aguaray, Paraguay.

Email:jtorales@med.una.py

Submitted: 4 August 2017; Accepted: 2 January 2018

\section{Introduction}

Homosexuality still suffers from negative stereotypes that influence public perception. ${ }^{1}$ There has long been prejudice and discrimination against lesbian, gay, bisexual, and transgender (LGBT) people; even the Old Testament condemns homosexuality. ${ }^{2}$ Currently, homosexuality is not considered a disease although biological, genetic, psychological, and social causes might be involved..$^{3-5}$ In 1973, the American Psychiatric Association removed homosexuality from the Diagnostic and Statistical Manual of Mental Disorders. ${ }^{6}$ Currently, homosexuality is considered a healthy expression of sexuality. ${ }^{7}$ In 1990, the World Health Organization removed homosexuality from the International Classification of Diseases. ${ }^{8}$ Nonetheless, heterosexist ideology influenced by Christianity remains dominant in Western culture. ${ }^{9}$

Homophobia among health professionals may complicate the doctor-patient relationship, therapeutic alliance, and treatment of LGBT people who often avoid routine medical care for fear of being discriminated against or stigmatised..$^{10,11}$

Attitude is defined as the sum of feelings, prejudices, ideas, fears or beliefs that an individual has about a specific issue. Its expression is the opinion of acceptance or rejection by an individual about a particular condition. Attitude may be also considered a set of beliefs, feelings, and tendencies that include three components: cognitive, affective, and behavioural. ${ }^{12-14}$

At the National University of Asuncion, Paraguay, healthcare for the LGBT population is part of the curricula for medical students whose knowledge of LGBT health needs to be improved..$^{15,16}$ Negative attitudes of medical students towards LGBT individuals can discourage them from seeking medical attention and to feel badly treated or even discriminated against. It is important to study the 
attitude of medical students towards homosexuality because prejudice damages the quality of healthcare for LGBT patients. ${ }^{17,18}$ This study aimed to describe the attitude of medical students at the National University of Asuncion, Paraguay towards homosexuality.

\section{Methods}

This study was approved by the Socio-anthropology Department of the School of Medical Sciences, National University of Asunción, Paraguay. Informed consent was obtained from each participant; anonymity was guaranteed. This observational, cross-sectional study was conducted in June 2016 in consecutive medical students from the National University of Asunción (Santa Rosa del Aguaray branch), Paraguay. Based on the formula to contrast means bilaterally, a sample size of 54 was needed to achieve a confidence level of $95 \%$, a statistical power of $90 \%$, an accuracy of $5 \%$, and a variance of $64.32 .^{18}$

The 10-item attitude towards homosexuality scale (EAH-10) ${ }^{19}$ was used to assess participants' acceptance/ rejection of homosexuals as individuals, homosexuality as a sexual orientation, and public manifestations of homosexuality. Scores for each item range from 1 (strongly disagree) to 5 (strongly agree). Total score ranges from 10 to 50 . A score below the 27 th percentile indicates nondiscrimination; percentiles higher than the cut-off indicate a negative attitude (discrimination) towards homosexuality. The EAH-10 has high internal consistency (Cronbach $\alpha$ $=0.87$ ) and has a two-interrelated-factor structure, with a good fit (goodness-of-fit index $=0.97) .{ }^{19}$

The sociodemographic profile of participants was recorded and included age, sex, academic year, ${ }^{14}$ religion (Catholic, non-Catholic Christian, atheist, agnostic, other), and whether they had homosexual friends.

Data were analysed using the Epi Info software 7.2 free version (Centers for Disease Control and Prevention, Atlanta, USA). Student's $t$ test and analysis of variance were used to compare the means of variables with normal distribution. Correlation between EAH-10 score and other variables was determined using the Pearson's coefficient.

\section{Results}

A total of 48 female and 29 male participants (mean age, $21 \pm 2$ years) were included. Those who failed to return a completed questionnaire were excluded. Of the participants, $92.2 \%$ were single. Most were in the second year $(42.9 \%)$ of study, followed by first year $(28.6 \%)$ and third year (28.6\%). Most were from Asunción (59.7\%), followed by peripheral cities $(28.6 \%)$ and Central Province $(11.7 \%)$. Most were Catholic (71.4\%), followed by non-Catholic Christian (10.4\%), agnostic $(9.1 \%)$, atheist $(2.6 \%)$, and other $(6.5 \%)$. Most belonged to the middle socioeconomic stratum (79.2\%), followed by the lower (18.2\%) and higher $(2.6 \%)$ socioeconomic stratum. $76.6 \%$ were regular students. $71.4 \%$ reported having at least one homosexual friend.

The mean EAH-10 score was $27.23 \pm 9.379$, with a normal distribution $(\mathrm{ZK}-\mathrm{S}=0.498, \mathrm{p}=0.965)$. Using the cut-off of 27 th and 73rd percentiles of the EAH-10 score (21 and 34 points, respectively), $42.9 \%$ of the participants were indifferent or undecided in their attitude towards homosexuality and $28.6 \%$ were discriminatory.

Age was not associated with EAH-10 score $(r=-0.62$, $\mathrm{p}=0.593)$. Having homosexual friends was associated with a lower EAH-10 score $(t=-3.447$ [75], $\mathrm{p}=0.001$, Table). The effect size was calculated through Hedge's g (0.861) and $\mathrm{R}^{2}(0.16)$.

\section{Discussion}

In our study, most medical students had an indecisive attitude towards homosexuality, and $28.6 \%$ had a negative attitude. This percentage is higher than that reported in other studies in Paraguay and Mexico. ${ }^{16,20}$ This could be due to the sample characteristics and enrolment procedure (nonprobabilistic of consecutive cases). Age was not correlated with EAH-10 score; this is in line with a similar study in Paraguay. ${ }^{16}$ There was no significant difference in EAH-10 score between sexes. In contrast, in India and the United States, women have a more positive attitude than men towards homosexuality. ${ }^{10,21}$

Among medical students in Zagreb, Croatia, nonCatholic Christians have been reported to have a higher level of rejection towards homosexuality, whereas Catholics had an intermediate level of rejection and other religions

Table. Association of medical student characteristics with attitude towards homosexuality scale (EAH-10).

\begin{tabular}{|lcc|}
\hline Variable & $\begin{array}{c}\text { Means } \pm \text { SD } \\
\text { EAH-10 score }\end{array}$ & p Value \\
Sex & & 0.724 \\
Female & $26.94 \pm 8.48$ & \\
Male & $27.72 \pm 10.83$ & \\
\hline Do you have homosexual & & 0.001 \\
friends? & & \\
Yes & $25.05 \pm 9.06$ & \\
No & $32.68 \pm 7.96$ & \\
\hline Year & & 0.125 \\
First & $27.09 \pm 9.61$ & \\
Second & $29.39 \pm 8.12$ & \\
Third & $24.14 \pm 10.39$ & \\
\hline Religion & & 0.604 \\
Catholic & $27.38 \pm 9.47$ & \\
Non-Catholic Christian & $28.5 \pm 3.62$ & \\
Atheist & $19.5 \pm 13.43$ & \\
Agnostic & $24.43 \pm 8.44$ & \\
Other & $30.6 \pm 14.92$ & \\
\hline
\end{tabular}


had a lower level of rejection. ${ }^{22}$ In our study, religion was not associated with EAH-10 score. This may be due to the small sample size.

Having homosexual friends is associated with a lower EAH-10 score and may predict less rejection of homosexuality. ${ }^{23-25}$ Having social contact with LGBT people, especially those who are victims of stigma and discrimination, may have a positive effect on attitude towards homosexuality. ${ }^{23-25}$

This study has limitations, including the small sample size, the lack of prior identification of independent variables that could affect attitude towards homosexuality, and the simplistic statistical analysis.

\section{Conclusion}

Education about health issues of LGBT people is needed for medical students. Attitude towards homosexuality is an important issue in medical education. It can affect the quality of care for LGBT patients, the doctor-patient relationship, and the medical assessment of health needs. ${ }^{26}$ Health is a fundamental human right. ${ }^{27}$

\section{Declaration}

The authors have no conflicts of interest to disclose.

\section{References}

1. Álvarez H. Percepción social de la homosexualidad [in Spanish]. Revista de Ciencias Médicas de la Habana 2015;21:75-83.

2. Barrios I, Torales J. La homosexualidad desde el punto de vista científico actual [in Spanish]. An Fac Cienc Méd (Asunción) 2017;50:85-8. eross ret

3. Castellanos González MA, Arce Gómez DL, Reina Castelanos LM, Lescay Rojas A, García Megret E. Homosexualidad, familia, violencia y drogadicción [in Spanish]. MEDISAN 2008;12(2).

4. Masters WH, Johnson VE, Kolodny RC. La sexualidad humana [in Spanish]. La Habana: Científico-Técnica; 1987.

5. Kolodny RC, Masters WH, Johnson VE. Tratado de medicina sexual [in Spanish]. La Habana: Científico-Técnica; 1985.

6. American Psychiatric Association. Diagnostic and Statistical Manual of Mental Disorders. 5th ed. Arlington: American Psychiatric Association; 2013.

7. Campo-Arias A, Herazo E, Cogollo Z. Homophobia among nursing students [in Spanish]. Rev Esc Enferm USP 2010;44:839-43. Eross re

8. Organización Mundial de la Salud. CIE 10. Décima Revisión de la Clasificación Internacional de Las Enfermedades [in Spanish]. Trastornos Mentales y del Comportamiento: Descripciones Clínicas y pautas para el Diagnóstico. Madrid: Meditor; 1992.

9. de la Rubia JM, Valle de la OA. Las dos dimensiones del rechazo hacia las personas homosexuales [in Spanish]. Archivos de Medicina (Manizales) 2014;14:103-16.
10. Banwari G, Mistry K, Soni A, Parikh N, Gandhi H. Medical students and interns' knowledge about and attitude towards homosexuality. J Postgrad Med 2015;61:95-100. Eross re

11. Harrison AE. Primary care of lesbian and gay patients: educating ourselves and our students. Fam Med 1996;28:10-23.

12. Soto-Cáceres V. Actitudes sobre el aborto, matrimonio homosexual y otros aspectos socio sexuales en estudiantes del sexto año de medicina humana en una universidad estatal [in Spanish]. Revista del cuerpo médico del Hospital Nacional Almanzor Aguinaga Asenjo 2014;7:610.

13. Summers G. Medición de Actitudes [in Spanish]. México: Editorial Trillas; 1979.

14. Diegez Ruibla JL, López Castedor A, Suerio Domínguez E, López Sánchez F. Propiedades psicométricas de la escala de actitudes hacia la sexualidad (ATSS) ampliada [in Spanish]. Cuadernos de medicina psicosomática y psiquiatría de enlace 2005;54:46-56.

15. Dirección Académica de la Facultad de Ciencias Médicas de la Universidad Nacional de Asunción. Malla curricular y programas de estudio de la carrera de Medicina [in Spanish]. Asunción: Dirección Académica; 2016.

16. Barrios I, Miltos V, Montiel J, Piris G, Torales J, Arce A. Actitudes de los estudiantes de ciencias básicas de la carrera de medicina de la Universidad Nacional de Asunción hacia la homosexualidad [in Spanish]. Revista Paraguaya de Psiquiatría 2014;2:8-17.

17. Campo-Arias A, Oviedo H, Herazo E. Correlación entre homofobia y racismo en estudiantes de medicina [in Spanish]. Psicología desde el Caribe 2014;31:25-37. Eross re

18. Costa PA, Almeida R, Anselmo C, Ferreira A, Pereira H, Leal I. University students' attitudes toward same-sex parenting and gay and lesbian rights in Portugal. J Homosex 2014;61:1667-86. cross ret

19. de la Rubia JM, Martínez J. Escala de Actitud hacia la homosexualidad: propiedades psicométricas y aspectos diferenciales por sexos [in Spanish]. Revista Internacional de Ciencias Sociales y Humanidades 2011;21:105-24.

20. de la Rubia JM, Valle de la O, García-Cadena C. Variables related to sexual prejudice among Mexican health science students. Medicina Universitaria 2015;17:20-9. cross re

21. Lafave A, Herbert H, Gomez O. The relationship between gender and heterosexual attitudes toward homosexuality at a conservative Christian university. J Res Christian Edu 2014;23:283-93. Eross ref

22. Grabovac I,Abramovic M,Komlenovic G, Milosevic M, Mustajbegovic J. Attitudes towards and knowledge about homosexuality among medical students in Zagreb. Coll Antropol 2014;38:39-45.

23. Thanh Nguyen T, Kimura K, Morinaga Y. Homonegative attitudes and their correlates among Vietnamese college students. Psychol Rep 2016;118:849-60. Eross re

24. Verweij KJ, Shekar SN, Zietsch BP, Eaves LJ, Bailey JM, Boomsma DI, et al. Genetic and environmental influences on individual differences in attitudes towards homosexuality: an Australian twin study. Behav Genet 2008;38:257-65. Eross re

25. Wilkinson W. Religiosity, Authoritarianism and homophobia: a multidimensional approach. Int J Psychol Relig 2004;14:55-67. cross re

26. Silberman P, Buedo PE, Burgos LM. Barriers on the sexual health care in Argentina: perception of women who have sex with women [in Spanish]. Rev Salud Publica (Bogota) 2016;18:1-12. cross re

27. Lim FA, Hsu R. Nursing students' attitudes toward lesbian, gay, bisexual, and transgender persons: an integrative review. Nurs Educ Perspect 2016;37:144-52. Eross re 